\title{
LA 'EPOPEYA', NOMBRE COMÚN: ALGUNAS CONSIDERACIONES SOBRE ARISTÓTELES, POÉTICA 1447 A 28 - B 16 Y SU RECEPCIÓN EN LA TEORÍA LITERARIA RENACENTISTA ${ }^{1}$
}

An anonymous interpolation according to modern textual criticism, the word $\dot{\varepsilon} \pi$ o $\pi$ oli $\alpha$ in Poetics 1447 a 28 was viewed among Renaissance scholars as originally written by Aristoteles, thus giving the text a puzzling meaning - epic may be written both in verse and prose-. This article analyzes some implications of that reading in the interpretation of its broader Aristotelian context by humanists as well as in the Renaissance theory of literary genres.

La recepción de la Poética aristotélica en el Renacimiento muestra pocos episodios tan curiosos como el relativo a 1447 a 28 - b 16. El impacto de este pasaje en la teoría literaria de la época es de no poca monta y, sin embargo, se debe sobre todo a una precisa palabra que - si la crítica textual está, como parece, en lo cierto- constituye interpolación de mano ajena. El pasaje está debidamente enmendado en las ediciones modernas al uso pero, por lo mismo, su importancia suele escapar a los estudiosos actuales de la poética renacentista; y es que, en efecto, no ofrece hoy el mismo significado que tuvo para los preceptistas del siglo XVI. Naturalmente, hay que exceptuar a figuras como Weinberg o García Berrio; con todo, sus observaciones al respecto se centran principalmente en los comentarios quinientistas a la obra aristotélica, y, si atinadas y fecundas por las claves que brindan de ulterior análisis, son apuntes diseminados en obras de más amplio propósito. Sirvan estas breves páginas monográficas para recapitular la cuestión, añadiendo algunos datos sobre los ya suministrados por aquellos autores.

En el contexto inmediatamente anterior a las líneas citadas, Aristóteles distingue las artes imitativas de acuerdo con el medio de mímesis. Todas las que se enumeran - epopeya, tragedia, comedia, poesía ditirámbica, en parte la

\footnotetext{
1 Deseo expresar mi agradecimiento a la Prof. D." Luisa López Grigera, con cuyas orientaciones y estímulo está en deuda este artículo; también a los Profesores D. Juan Gil, D. José M. Maestre y D. Antonio Villarrubia, quienes leyeron el borrador y lo enriquecieron con valiosas sugerencias.
} 
aulética y la citarística - utilizan el ritmo, el lenguaje o la armonía, bien combinada, bien separadamente; así, las que se expresan sólo con ritmo y armonía son la aulética y la citarística; la danza se sirve sólo del ritmo, sin armonía. Ahora bien, ¿cómo se llama el arte que hace la mímesis solamente con el lenguaje, ya sea en prosa, ya en verso? A ello responde el pasaje de nuestro interés, que reproduzco basándome en la edición de R. Kassel ${ }^{2}$ :

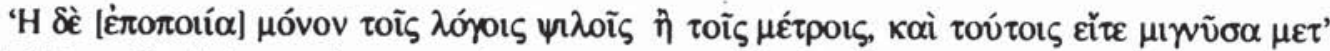

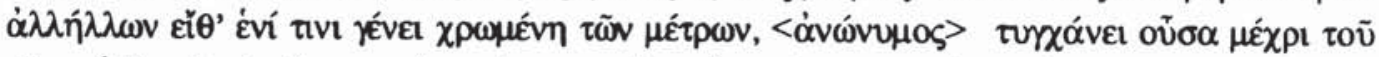

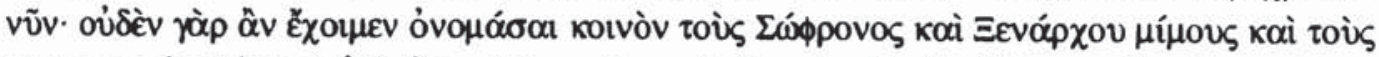

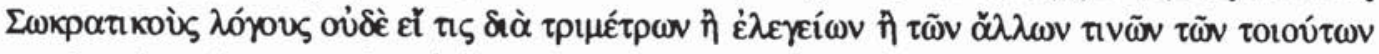

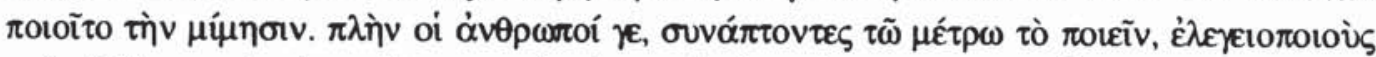

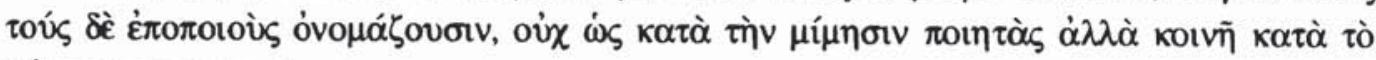

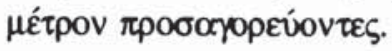

\section{Doy ahora una traducción española, que es de V. García Yebra ${ }^{3}$ :}

Pero el arte que imita sólo con el lenguaje, en prosa o en verso, y, en este caso, con versos diferentes combinados entre sí o con un solo género de ellos, carece de nombre hasta ahora. No podríamos, en efecto, aplicar un término común a los mimos de Sofrón y de Jenarco y a los diálogos socráticos, ni a la imitación que pudiera hacerse en trimetros o en versos elegíacos u otros semejantes. Sólo que la gente, asociando al verso la condición de poeta, a unos llama poetas elegíacos y a otros poetas épicos, dándoles el nombre de poetas no por la imitación, sino en común por el verso.

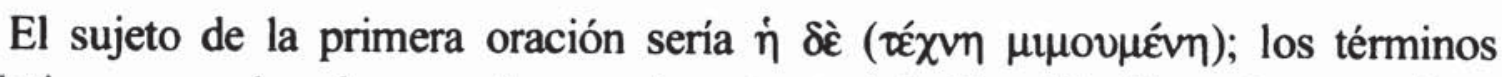

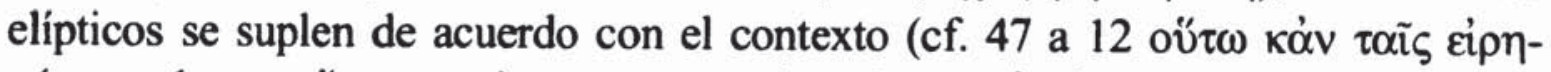

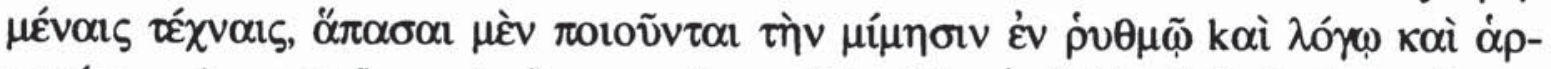

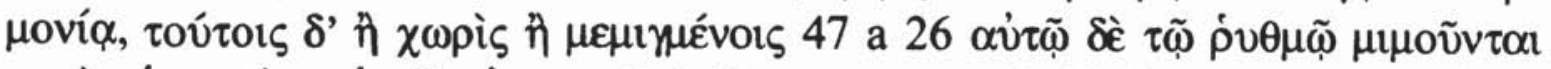

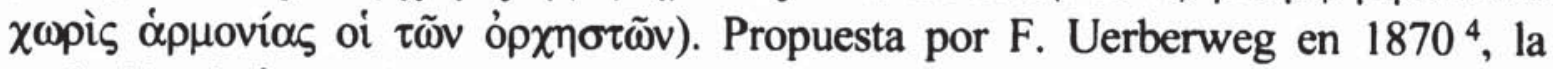
seclusión de غ̇лолolí $\alpha$ parece exigida, en opinión de los estudiosos ${ }^{5}$, por diversas

${ }^{2}$ R. Kassel, Aristotelis de arte poetica liber, Oxford, 1988 [= 1965], pp. 3-4. Me aparto, sin embargo, con V. García Yebra (Poética de Aristóteles, ed. trilingüe, Madrid 1974, pp.

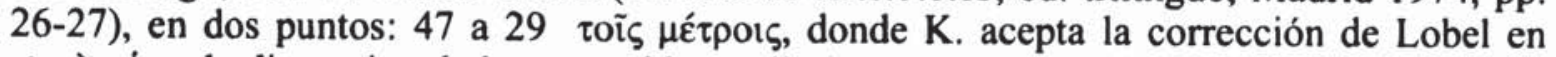
$<\kappa \alpha \grave{>} \dot{\eta} . .$. ; la disyuntiva da buen sentido, y eliminarla implicaría una discrepancia respecto a las lecturas renacentistas que no haría sino distraernos de la cuestión aquí analizada; 47

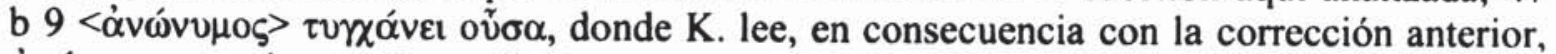

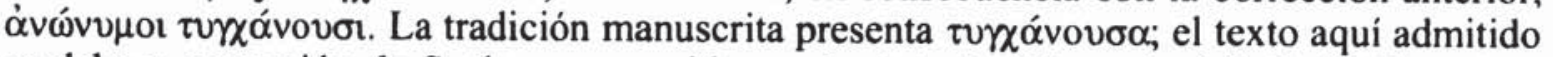
se debe a corrección de Suckow, requerida por la sintaxis del pasaje (cf. G. F. Else, Atistotle's Poetics: The Argument, Cambridge, Mass., 1963, pp. 29-30, si bien este autor acepta

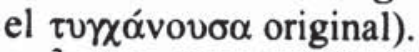

3 Op. cit., pp. 128-129.

4 Aristotelis Ars Poetica ad fidem potissimum codicis antiquissimi $A^{e}$ [Parisinus 1741], Berlín 1870.

5 Cf. F. E. Housholder, Jr., "The first chapter of the Poetics», AJP 66, 1945, pp. 266-278, esp. 273-274; Kassel, ed. cit., p. xi. 
razones, entre las que aquí cabe destacar dos: 1) para mantener el vocablo, habría

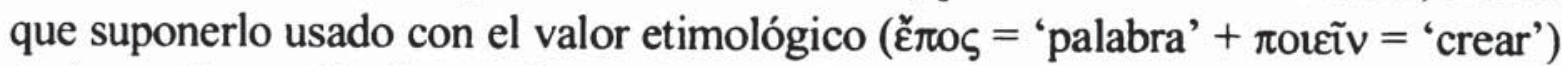
de 'creación realizada mediante el mero lenguaje' (de donde la posibilidad del verso, o la prosa; el alemán ofrece una traducción ajustada de este sentido en el término 'Wortdichtung'); ahora bien, ع̌ te, con el valor de 'poesía épica' en sentido estricto, o 'poesía en verso heroico' (por ejemplo, en el mismo capítulo, dieciséis líneas más arriba); de haber introducido una acepción anómala, Aristóteles nos hubiera prevenido con una redefinición explícita del término, como también hubiese hecho al volver a utilizarlo ya en su acepción convencional, para no confundir al lector con la anfibología: ello no parece ocurrir, sin embargo; 2) la versión árabe de la Poética, realizada en el s. $X$ sobre una traducción siríaca de un códice griego perdido - circunstancia que, desde luego, hace sólo hasta cierto punto fiable este testimonio textual-, no traduce de hecho el término en cuestión ${ }^{6}$. La adición de $\dot{\alpha} v \omega v u \mu \varsigma_{\text {, }}$ obra de $\mathrm{J}$. Bernays ${ }^{7}$, es coherente con aquella atétesis y además está confirmada por la traducción árabe. Así restaurado, el pasaje se incardina de modo más natural en la dirección lógica del contexto anterior $y$, sobre todo, del posterior: en efecto, la explicación que sigue («No podríamos, en efecto, aplicar un término común a los mimos de Sofrón..») parece más congruente con una afirmación de que no existe un nombre ( $\dot{\alpha} v \omega ́ v u \mu \varsigma)$ para el género que imita en simple lenguaje en prosa y

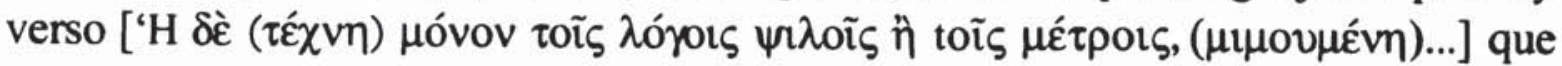
en el caso de que conservemos el texto transmitido (véase más abajo). Vahlen ${ }^{8}$ trató, contra viento y marea, de salvar la forma غ̇лo 'Wortdichtung'; a la misma causa dedicó, en nuestro siglo, esfuerzos casi desesperados S. M. Pitcher ${ }^{9}$. Sin embargo, hoy día aquellas enmiendas se aceptan generalmente.

Ahora bien, a los humanistas del Renacimiento no les asistía la traducción árabe de la Poética; tampoco, seguramente, la osadía o la perspicacia crítica necesarias para corregir al Estagirita en aquel sentido. El texto con el que se

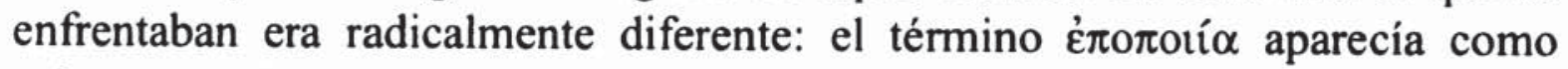
sujeto auténtico de la oración; repárese, también, en la presencia del original $\tau \cup \gamma \chi \alpha ́ v o v \sigma \alpha$, frente a la adición y enmienda de las ediciones modernas:

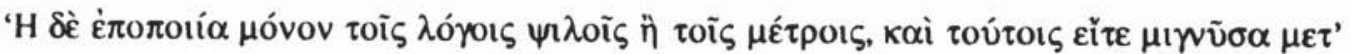

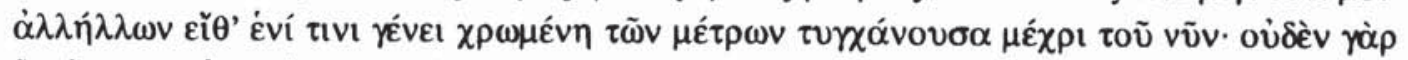

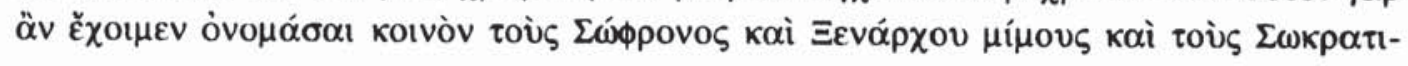

${ }^{6}$ Cf. Kassel, ed. cit., p. 3.

Über Wirkung der Tragödie, Breslau 1857, pp. 186.

${ }^{8}$ Cf. Gesammelte Philologische Schrifien, I (1858-1874), Hildesheim-N. York 1970.

${ }^{9}$ "Epic, as I here define it», AJP 65, 1944, pp. 266-278, convincentemente refutado, a mi entender, por Housholder, en el art. cit. 


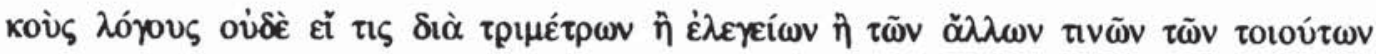

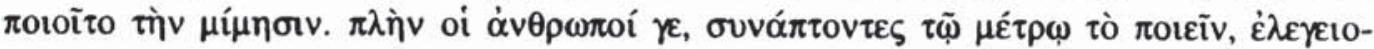

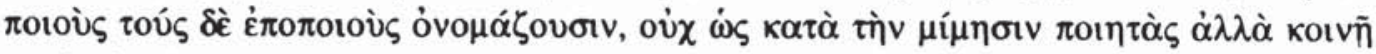

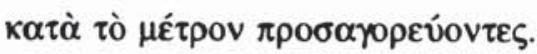

He aquí la primera oración (la verdaderamente nuclear en todo el proble$\mathrm{ma}$ ) en tres versiones latinas renacentistas, realizadas respectivamente por F, Robortello, P. Vettori y A. Riccoboni ${ }^{10}$ (las presento en este mismo orden):

Nudis autem sermonibus, siue metris solummodo epopoeia utitur, metrorum quidem hactenus siue mixtis aliquibus inter se, siue generis eiusdem alicuius (p. 11) ${ }^{\prime \prime}$.

Epopoeia uero solum sermonibus nudis, uel metris, et his quidem siue mixtis illis inter se, siue uno quodam genere metrorum utens, ut usque ad hanc diem fecit (p. 11).

Epopoeia uero solum sermonibus nudis uel metris, et his siue mixtis inter se siue uno aliquo genere utens metrorum, qualis fuit usque adhuc (p. 129).

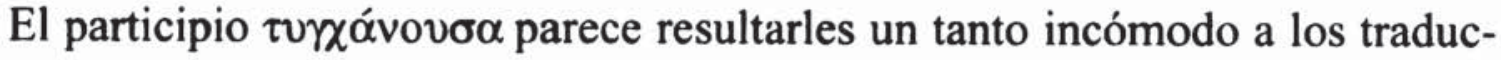
tores; Robortello lo omite; Vettori y Riccoboni le dan un giro que no es desatinado (literalmente, la secuencia podría interpretarse como «encontrándose <así> hasta el presente»). Más interesa observar que los tres toman el participio

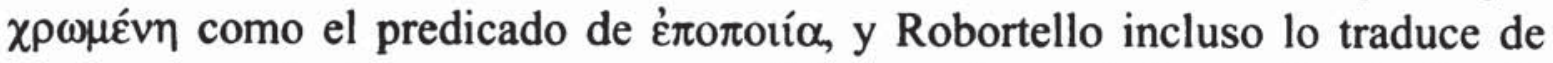
forma personal: «la epopeya no es» - diríamos adaptando la versión de García Yebra, reproducida arriba - «la que hace su imitación en prosa o en versos, y éstos, mezclándolos o bien usando ( $\chi \rho \omega \mu \varepsilon ́ v \eta)$ una sola especie de ellos», sino simplemente es la que se sirve de aquellos instrumentos. Esta sutil diferencia será relevante en algunos lugares de nuestra posterior discusión. El significado del pasaje completo, de acuerdo con el texto renacentista, vendría a ser el siguiente (entre paréntesis suplo sobreentendidos y añado glosas explicativas):

Pero la epopeya (es) la que usa de la prosa o de los versos, y éstos, bien mezclándolos unos con otros, bien empleando sólo una clase. No podriamos, en efecto, aplicar un término común (es decir, ningún otro término común más que el de 'epopeya' en

${ }^{10}$ Francisci Robortelli Vtinensis in librum Aristotelis de Arte Poetica Explicationes, qui ab eodem authore ex manuscriptis libris multis in locis emendatus fuit, ut iam difficillimus ac obscurissimus liber a nullo ante declaratus, facile ab omnibus possit intelligi, Florentiae 1548; Petri Victorii Commentarii in primum librum Aristotelis de Arte Poetarum, positis ante singulas declarationes Graecis uocibus auctoris, iisdemque ad uerbum Latine expressis. Accesit rerum et uerborum memorabilium index locupletissimus, Florentiae 1560. A. Riccoboni Aristotelis Liber de Poetica ab A. Riccobono... Latine conuersa et clarissimis partitionibus ac notationibus ad oram libri positis illustrata, Venetiis 1584; cito por la ed. de García Yebra en op. cit., p. 129.

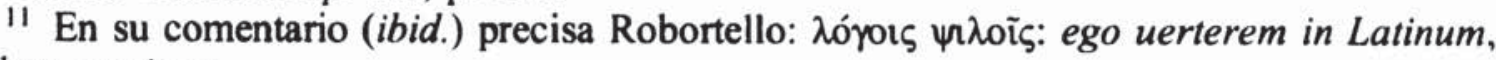
soluta oratione. 
sentido amplio e impropio, y de ahí que recurramos a él) a los mimos de Sofrón y de Jenarco y a los diálogos socráticos, ni a la imitación que pudiera hacerse en trímetros o en versos elegíacos u otros semejantes. Sólo que la gente, asociando al verso la condición de poeta (o tal vez, uniendo con el metro la palabra 'hacer'), a unos llama poetas elegíacos y a otros poetas épicos, dándoles el nombre de poetas no por la imitación, sino en común por el verso.

¿Cómo reaccionaron los estudiosos de poética y de la Poética ante estas líneas, que reflejaban un concepto de 'epopeya' tan diverso del original y del preconizado por el propio Aristóteles: es decir, el de 'arte de imitar en hexámetros' (49 b 21)? Ilustremos esta cuestión con algunos ejemplos.

Autores de poéticas como Viperano y Minturno parafrasean el texto aristotélico - aunque sin mencionar al Filósofo-, pero no se andan ni perplejos ni torpes ante la cuestión que suscita. Al comenzar sus instrucciones sobre el género épico, el primero establece que 'epopeya' tiene el sentido etimológico

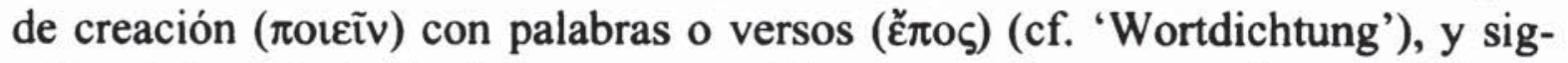
nifica imitación hecha bien en prosa, bien en verso; se trataría, pues, de un

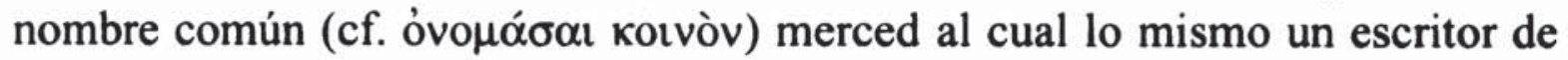
diálogos que cualquier poeta puede, en principio, ser considerado 'épico'. Ahora bien - continúa-, aunque Ě lingüística, sin embargo designa por excelencia al que es propio de los poetas, o sea, al verso, y de entre los tipos de versos se refiere, también por excelencia, al hexámetro ${ }^{12}$. De este modo, concluye, la epopeya es imitación en verso hexámetro. Para Minturno, los diálogos socráticos pueden incluirse en la poesía épica, al igual que la elegía y los yambos, y también —paso más allá respecto a Viperano- composiciones de los que, como Empédocles, escriben en verso sin hacer propiamente imitación, ya que de otro modo no existiría un término capaz de designar en común a las formas literarias que, como aquéllas, se sirven (recuérdese cómo en traducciones renacentistas el predicado de غ̇ $\pi$ o$\pi$ oía era el participio $\chi \rho \omega \mu \varepsilon ́ v \eta)$ sólo del lenguaje, sea en prosa, sea en verso. Sería, pues, lícito - concede Minturno- emplear para todos los que usen exclusivamente la palabra, sin acompañamiento de melodía o baile, el nombre de poetas épicos, si bien —advierte - este término se destina particularmente

12 De epopoeia (cap. II, lib. II). Nunc Epopoeiae naturam explicabimus, quae ceteris et

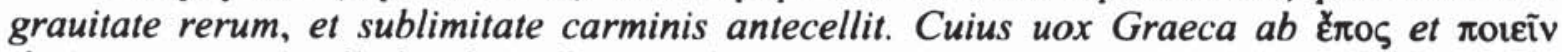
deriuata, quorum illud uel 'uerbum' uel 'carmen', hoc 'facere' seu 'fingere' significat, omnem uel soluta oratione, uel carminibus expressam fictionem significat; qua communi nominis deductione compositores dialogorum et poetae quilibet epici uocari possunt. Ac

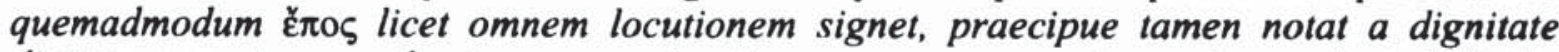
dictionem poetae, quod est carmen, sic etiam saepe carmen hexametrum ob stabilitatis, grauitatis et magnitudinis excellentiam commune nomen proprium fecit [G. A. Viperano, De Poetica libre tres, Antuerpiae MDLXXIX (= ed. facs. 1967), pp. 70-71]. 
a los que hacen imitación en verso heroico ${ }^{13}$. La fórmula con que estos autores resuelven el problema resulta socorrida. Viperano explica el uso anómalo del término como una natural posibilidad de su etimología (al igual que Vahlen), y se detiene a razonar su conexión con el uso convencional apelando a una especialización semántica debida a factores de axiología estética. Minturno, por el contrario, sólo justifica el fenómeno en virtud de una carencia de nomenclatura, sin pararse a explicar por qué, para cubrir esa carencia, se elige precisamente el nombre de épica (aunque tal vez la razón etimológica le parecía, por obvia, indigna de mención). Ahora bien, ambos dejan claro que la epopeya, así entendida, no refleja más que una virtualidad o abstracción terminológica, y procuran deslindarla del poema épico propiamente dicho, insistiendo en que tal es el concepto operante del término en la praxis de los géneros literarios. De este modo despachan la cuestión suscitada por el texto aristotélico y, a la hora de preceptuar la epopeya, pueden libremente centrarse en el poema heroico clásico, sin la necesidad de introducir un incómodo replanteamiento del género de acuerdo con las (falsas) instrucciones del Estagirita. Con todo, en sus obras quedaba escrito que la epopeya podía escribirse tanto en prosa como en verso: afirmación que, sacada de su original contexto, tendría poderosas consecuencias.

Los autores analizados ofrecían, como vimos, una solución simple. A los comentaristas de la Poética, por el contrario, el pasaje pudo causarles algunos quebraderos de cabeza ${ }^{14}$. A veces el comentarista militaba entre los defensores radicales de la necesidad del verso en la poesía, objeto de famosa polémica en la época, pero contra este principio se alzaba el texto presente, que autoriza nada menos que a la epopeya a asumir la prosa tanto como el verso. La respuesta ante esta contradicción no fue, frecuentemente, la de expresar discrepancia respecto al Estagirita, sino la de forzar el sentido del pasaje aristo-

${ }^{13}$ Sunt et Socratici sermones, et Alexamenei, qui quidem certe oratione ipsa multorum mores, ingenium, doctrinam effingunt. Sed tamen eos nisi in Epica poesi percenseas, non erit profecto nomen, quod cum mimis, quos Xenarchus aut Sophron commentatus est, commune illis esse reperias, ac ne iambis quidem, nec elegis, nec siquod eiusmodi genus est imitandi. Nam quamquam proprie priuatimque poetae hi sunt, qui carminibus actiones hominum Deorumue effingunt, hoc tamen nomine appellantur, et quicunque oratione imitantur, uel pedibus colligata uel soluta, et qui uersibus sine imitatione rem quamlibet exponunt. Quos omnes, dummodo neque cantu neque saltatione utantur, Epicos nominemus licebit, etsi iis praecipue id nominis tribuitur, qui uersu heroo poema componunt [A.S. Minturno, De poeta, Venetiis MDLIX (= ed. facs. Munich 1970), pp. 26-27]. En el pasaje de la Poética que estudiamos, a continuación de la última línea reproducida, Aristóteles contrastaba a Homero con Empédocles, afirmando que sólo tenían en común el verso. Antes se ha dicho que la epopeya es el arte que usa el lenguaje; por ello Minturno incluye en el término también a Empédocles y a los que, como él, usan del verso sin hacer propiamente imitación.

${ }^{14}$ Cf. A. García Berrio, Introducción a la poética clasicista: Cascales, Barcelona 1975, pp. 73-75. 
télico para reducirlo a aquel postulado: empeño que, previsiblemente, dio pie a notables perversiones filológicas. Ejemplo ilustre es el de Pietro Vettori, cuyo comentario a la Poética es, salvando puntos como el que nos interesa, uno de los más fieles y plenos de sutileza y profundidad exegética entre los producidos en la Italia del XVI ${ }^{15}$. García Berrio (p. 74) y Weinberg (p. 463) apuntaron el caso; por la curiosidad que ofrece, valdrá la pena desarrollarlo (la exégesis de Vettori resulta a ratos embarullada; en mi exposición, que tendrá no poco de interpretación, me permitiré alterar el orden argumental del autor).

Puesto a demostrar que Aristóteles no permitió una epopeya en prosa, Vet-

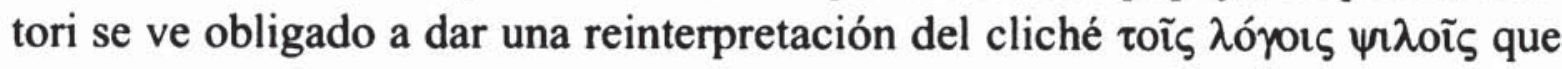
excluya, lógicamente, el significado, de 'prosa'. En su traducción lo recoge como sermonibus nudis; el sentido sería el de "discursos desnudos», donde 'discurso' ( $\lambda$ ójos) equivaldría a 'lenguaje métrico o discurso en ese lenguaje' ${ }^{16}$. Ahora bien, ¿puede $\lambda$ ó mente, aduciendo un ejemplo del Banquete de Platón [194-194 b]:

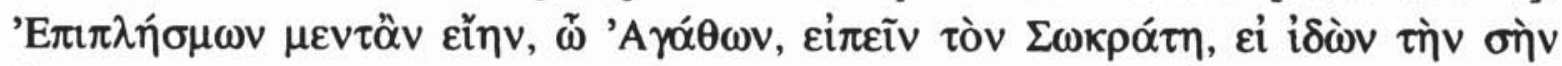

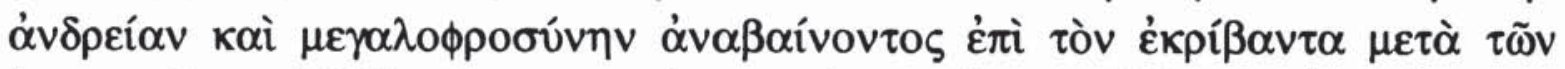

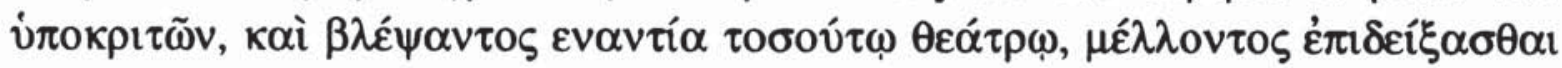
$\sigma \alpha v \tau o v \tilde{~} \lambda o ́$ ov, , $\kappa \tau \lambda$., si bien admite que la palabra también podría significar pieza teatral (fabella, p. 12). Y sin embargo - continúa Vettori- hay algunos

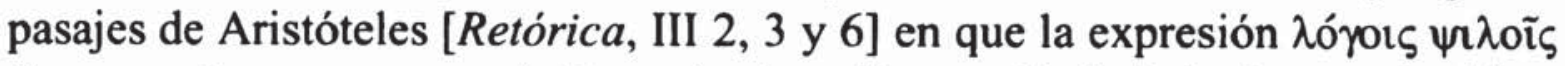
figura en franca contraposición a $\tau \grave{\alpha} \mu \varepsilon \varepsilon^{\prime} \rho \alpha^{17}$ : ¿es ello indicio de que significa, sin más, prosa? De ningún modo, responde. Para expresar el concepto de prosa en oposición a metro, ya se basta el Filósofo en otros lugares de la Retórica

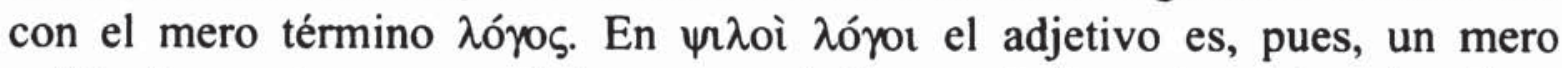
calificativo externo que añade una precisión semántica sobre $\lambda$ óyor (aquí, en Retórica $=$ 'prosa') y el conjunto significa, por tanto, 'prosa desnuda de otros adornos de estilo'. Desde tal perspectiva, también en este lugar de la Poética puede tomarse el adjetivo $\psi \imath \lambda$ iò como calificativo externo de $\lambda$ ópo (sustantivo ahora usado con el mismo valor que, supuestamente, tendría en Platón), y así, el sentido global es el de 'lenguaje métrico que está desnudos de otros elementos' (a saber, los otros medios de imitación que son la armonía y el ritmo, enumerados en el contexto anterior). Para sostener semejante interpretación, Vettori se ve obligado a retorcer el significado de la disyuntiva siguiente, $\hat{\eta}$

${ }^{15}$ Cf. B. Weinberg, A History of Literary Criticism in the Italian Renaissance. I, Chicago 1959, p. 461 ss.

${ }_{16}$ Perspicitur autem hinc גójov, supra ut docui, pro metrica oratione capiendum esse (p. 11).

${ }_{17}$ Robortello, op. cit. p. 12 cita esos mismos ejemplos de la retórica para demostrar que el sintagma en cuestión debe traducirse como oratio soluta, $i$. e., prosa. 


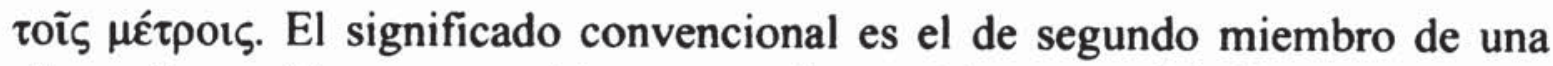
alternativa: o bien prosa o bien verso. En cambio, para el italiano es posible observar allí una especie de corrección sobre las palabras anteriores, dándole a la conjunción el significado de 'o mejor dicho' (uel potius). Así, el Estagirita habría afirmado en un primer momento que la epopeya es la que emplea sólo $\lambda$ óyor desnudos (con el valor que supuestamente le da Platón al término), pero al punto se percató de que ese vocablo, a fuer de ambiguo, podía inducir a confusión, y de este modo se apresuraría a precisar: "o mejor dicho, (es la que usa) sólo del verso" ${ }^{18}$.

Sin embargo Aristóteles - prosigue Vettori-sabría que la epopeya es poema heroico e imitación de personajes eminentes. Reconociéndose culpable de impropiedad designativa, el Filósofo se excusa alegando una razón de necesidad terminológica en la oración causal que sigue: no existe, en efecto, otro nombre común para abarcar los géneros citados a continuación, si exceptuamos el procedimiento que usa la gente - designar a los poetas como artífices de versos, sin tener en cuenta si hay o no imitación- (p. 13): según Vettori, Aristóteles ha seguido ese procedimiento, catalogando como epopeya el género que usa sólo el lenguaje métrico, sin más considerandos (pp. 13-14) ${ }^{19}$. 'Epopeya' sería, pues, nombre común para composición en verso, haya o no imitación (hay aquí coincidencia parcial con Minturno). Pero esta concepción tiene sus consecuencias en la restante lectura del pasaje. Entre los géneros comprendidos bajo el 'nombre común' están los mimos de Sofrón y Jenarco

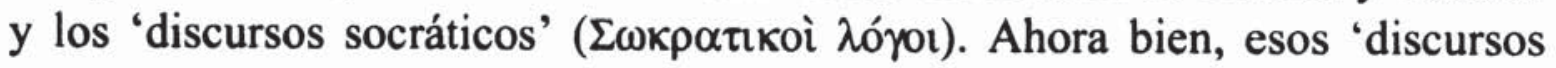
socráticos' ¿no son los diálogos platónicos, género en prosa? y de los mimos de Sofrón, ¿no dice el léxico de Suidas que están igualmente en prosa? ¿Cómo pueden ser entonces poesía, si ésta requiere el verso? ¿cómo, caer bajo la categoría de épica? Vettori arguye: los 'discursos socráticos' no son los diálogos platónicos, sino las fábulas de Esopo que, según Diógenes Laercio, Plu-

18 Perspicitur autem hinc גóyov, supra ut docui, pro metrica oratione capiendum esse; ita enim quoque hic poeticam orationem appellare coeperat [...] aut igitur, quod addidit,

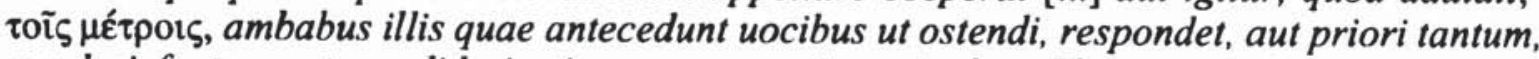
quod si factum est, crediderim ipsum, cum primun in hoc Platonem imitatus esset, qui

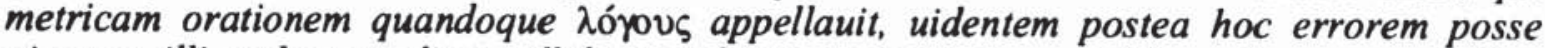
gignere, illi malo remedium adhibere uoluisse correxisseque et illius et suam ancipitem loquendi rationem.

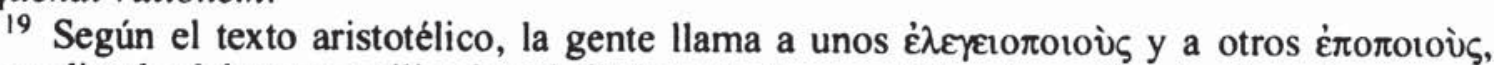
dependiendo del metro utilizado (el dístico elegíaco o el heroico, cf. más abajo la comparación de Homero y Empédocles), sin contar la presencia o no de imitación. Cuando dice que Aristóteles ha seguido esa costumbre llamando 'epopeya' a la composición que emplea el verso (cualquier tipo, ya limitándose a uno, ya mezclándolos), Vettori no debe apuntar a una coincidencia en el concepto preciso de poeta épico (ello sería una incoherencia), sino en el hecho de definir el nombre de acuerdo con el medio de expresión (el verso) y sin considerar el criterio de la mímesis. 
tarco [De cómo estudiar poesía $16 \mathrm{C}$ ] y Platón [Fedón $60 \mathrm{~A}$ ], puso en verso Sócrates (p. 14); pues de haber aludido a los diálogos, Aristóteles habría dicho

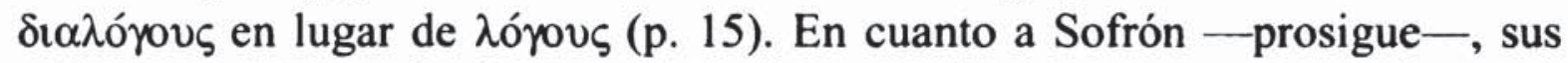
mimos se deben adscribir también al metro: los fragmentos recogidos por Ateneo y Demetrio ofrecerían vocabulario y estilo demasiado elevados como para caer en la prosa; el léxico de Suidas - añade - es sin duda una obra de notable erudición y autoridad, pero no pocas veces se equivoca, y ésta podría ser una de ellas; además - remata- ¿no deja ver claramente Aristóteles en fragmento transmitido por Ateneo [XI 505 c (Ar. fr. 72 Rose)], que dichos

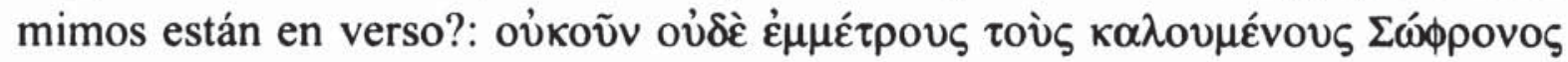

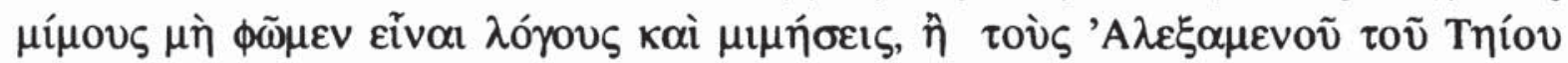

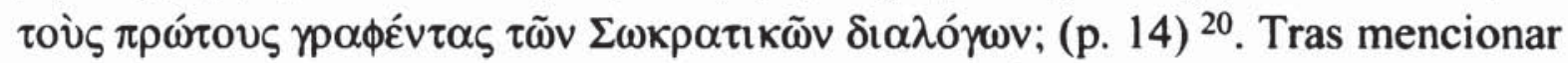

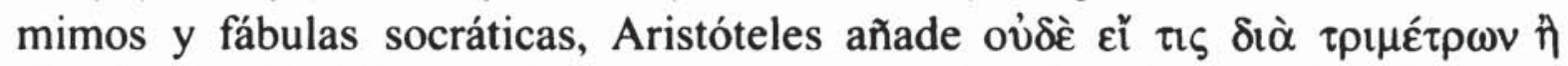

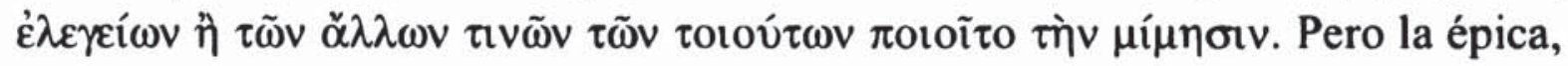
nombre común que abarca todas las especies ahí enumeradas, era según Vettori composición en verso, con o sin mímesis. Pues bien, esta premisa repercute decisivamente en la fisonomía misma del aquel texto griego de la Poética. Según análisis dicotómico del período (apoyado en la correlación ov̉ðév... ov̉$\delta \varepsilon ́$ ), mimos y fábulas serían la primera alternativa, composición en verso con mímesis; el miembro siguiente deberá entonces representar la segunda opción,

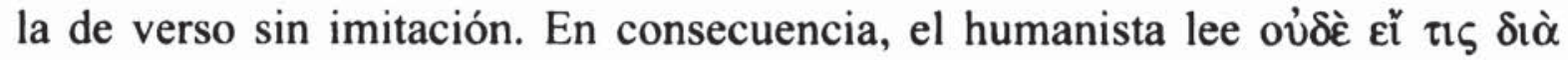

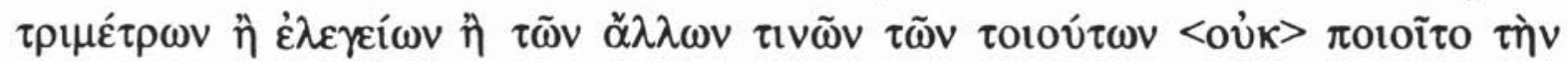
$\mu$ ín一oıv, con adición de un adverbio negativo que dice haber encontrado en algunos manuscritos $[i$. e., «pues ningún nombre común habría 1) para los mimos y fábulas (verso con mímesis) ni 2) para quien $<$ no $>$ hiciese la mímesis por medio de trímetros, versos elegíacos o algunos otros de tal clase»].

Como vemos, la interpolación de 'epopeya' ha provocado, en la particular exégesis de Vettori, una cadena de interesantes efectos. En primer lugar propicia una acepción nueva del término ( $\mathrm{y}$ con ello, la posibilidad de un concepto

${ }^{20}$ El pasaje es problemático (cf. Else, op. cit. p. 41); hoy día se lee de la manera

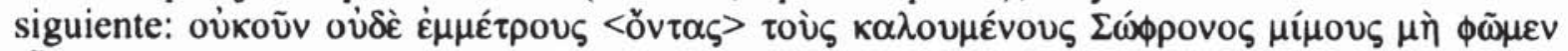

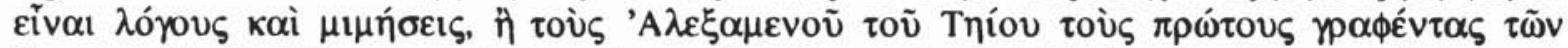
$\Sigma \omega \kappa \rho \alpha \tau \iota \kappa \tilde{v} v \delta \imath \alpha \lambda o ́ \gamma \omega v$; se observará que de este modo Aristóteles dice justamente lo contrario de lo que pretende Vettori, "¿vamos, pues, a decir que los llamados mimos de Sofrón, que ni siquiera están en verso, no son diálogos e imitación...?" (como pregunta negativa que espera respuesta afirmativa). Este sentido resulta, desde luego, más claro tras la adición del participio por Kaibel; ahora bien, la interpretación que cabe a partir del texto que tenía ante sí el humanista italiano debía transcurrir aproximadamente como sigue: «Asi pues, ¿no (oùđé) vamos a negar ( $\mu \grave{\eta} \phi \tilde{\omega} \mu \varepsilon v)$ que los llamados mimos de Sofrón son discursos e imitación en verso...?»; tampoco parece que, de este modo, el texto consienta la interpretación de Vettori. Conviene recordar, en fin, que los mimos de Sofrón y Jenarco estaban en prosa, y sólo en época posterior introduce Herodas el verso en este género. 
nuevo del género): composición que usa del verso, con o sin imitación. De

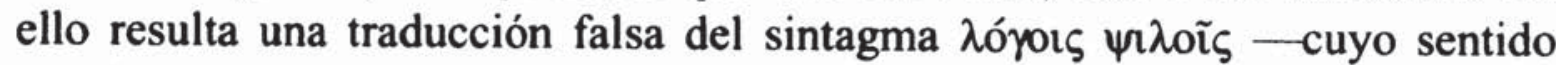
propio es el de 'prosa' - tanto aquí como, probablemente, en los pasajes

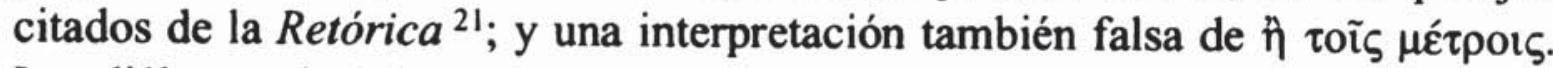
Los diálogos platónicos citados por el Filósofo pasan a ser las fábulas de Esopo en verso; los mimos de Sofrón, a género también en verso, con la consiguiente manipulación del fragmento de Aristóteles citado por Ateneo; en último término, la corrección del texto con la adición del adverbio negativo parece también obedecer a la interpretación que le impone al autor la presencia de 'epopeya'. Pero concausa esencial de todo lo dicho ha sido, naturalmente, el partidismo de Vettori a favor del verso como elemento necesario de la poesía. En efecto, aquellas manipulaciones se deben en buena medida al empeño consciente por ajustar el texto analizado a un principio contra el que, de hecho, se pronuncia Aristóteles. Matizando, pues, una afirmación anterior, digamos que no faltó aquí osadía crítica para enmendar al Estagirita, sólo que no se puso al servicio de la Poética, sino de la particular poética del comentarista ${ }^{22}$.

Las consecuencias distorsivas de la interpolación se extendían a otras obras de Aristóteles, según vimos. Pero quizá alcanzan también a la otra gran autoridad en materia de poética durante el Renacimiento, Horacio; tal parece ocu-

21 Sin embargo, A. Tovar, en su ed. con traducción de esta obra [Madrid $1990(=1953)$ ] vertía como 'prosa sencilla' (cf. el índice de tecnicismos retóricos, p. 245).

${ }^{22} \mathrm{El}$ hecho no es infrecuente en otros comentarios de la época. Caso extremo es el de Lodovico Castelvetro, quien, en su Poética d'Aristotele vulgarizzata e sposta (1570) aprovecha para construir una teoría literaria opuesta a la de Aristóteles (cf. Weinberg, I, p 69 ss. y art. cit. en n. 40). Entre los motivos de discrepancias está el de la necesidad del verso en poesía. Castelvetro defiende este principio y a él somete el texto aristotélico, forzando

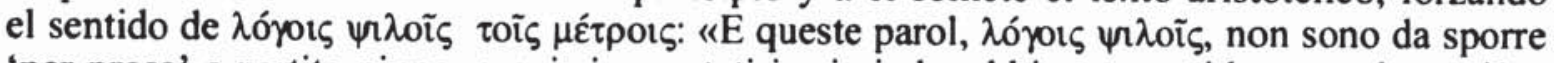
'per prosa' a partito niuno, e noi siamo stati i primi che abbiamo considerato e detto ciò a molti; della quale nostra considerazione essendo per lo nostro detto pervenuta ad alcun degli spositori alcuna notizia, ne favella in guisa che egli ne paia essere stato il trovatore, quantunque io non nieghi che si truovino queste parole in più autori poste in luogo di 'prosa'. Ora sono da prendere qui nell'uno de' due modi: o che si dica $\lambda$ óyors $\psi \tau i \lambda \sigma \tilde{c}$, cioè 'con parlare nudi', il che venga a dire senza vestimento e compagnia d'altri stormenti, armonia

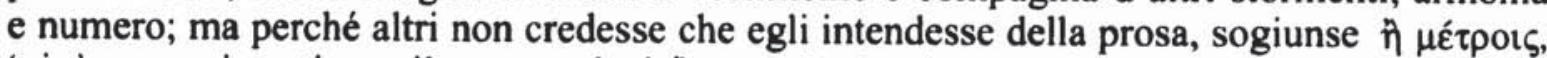
'cioè con misurati versi', sponendosi ĥ̀ per 'cioe', si come è cosa usitata di farsi appo Aristotele; o che si dica $\lambda$ ó́oı dividendo $i$ versi in due maniere, in umili e in alti» (ed. Werther Romani, 1978), I, p. 31 . En parejo sentido interpretan el pasaje otros partidarios del verso en poesía como B. Neroni en Se il verso è necessario nella poesia (1571) (cf. Weinberg, I, p. 513 ss., v. p. 515); N. Ellebodius, In Aristotelis librum de Arte Poetica paraphrasis (1572) (cf. Weinberg, I, pp. 519 ss., v. p. 520); Filippo Sasetti, Annotationi (1576) (cf. Weinberg, I, p. 573 ss., v. p.

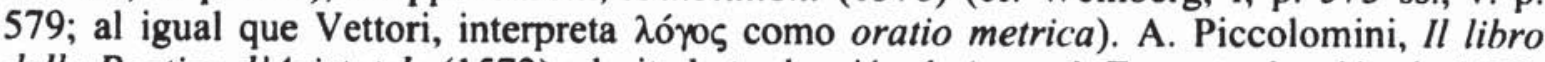
della Poetica d'Aristotele (1572) admite la traducción de 'prosa'. En su traducción de 1579, A. Riccoboni anota a propósito de î̀ $\mu$ é alusión a Castelvetro y a Vettori. Y apostilla al pasaje: An Epopoeia possit fieri soluta oratione (cf. Weinberg, I, p. 584). 
rrir, al menos, en los In librum de Arte Poetica Horatii Flacci scholia perutilia del humanista y geómetra valenciano Jaime Juan Falcó, compuestos hacia 1577 pero publicados por primera vez en 1600 con la edición de sus obras poéticas ${ }^{23}$. En el único tratado geométrico que publicó (De quatratura circuli, Valentiae 1587 Antuerpiae 1591), este autor trató - sin éxito, naturalmentede hallar la cuadratura del círculo; en sus escolios al Ars se empeñó - sin éxito, tampoco- en otra especie de cuadratura: demostrar que la poética horaciana es una preceptiva sobre la epopeya. Exceptuados los pocos pasajes en que Horacio - más volcado en la cuestión del drama - puede realmente tolerar aquella interpretación, dos son los procedimientos que emplea Falcó para convertir el Ars en un tratado sobre el género grande: 1) manipular el sentido de los versos horacianos; pero hay lugares en que resulta demasiado obvio que el referente es el drama, por lo que se recurre a: 2) utilizar el término 'épica' como inclusivo del poema heroico, de la tragedia y la comedia: de tal modo le cabe a Falcó decir que, al ocuparse de estos dos últimos géneros, Horacio está preceptuando sobre la epopeya. Como se ve, el artificio es de una fullería perfecta: el autor no apoya su tesis en una verdadera base argumental, ni en una interpretación honesta del texto horaciano, sino sólo en una vana coartada, en un juego de palabras que, evidentemente, no consigue el propósito buscado -identificar el Ars como preceptiva épica- más allá de la pura designación nominal; además, utiliza en franca anfibología el término 'epopeya', saltando de la acepción estricta a la amplia según su conveniencia y sin aviso: se atiene a la primera cuando el poema horaciano lo permite, y cuando no, echa mano de la segunda. Pero lo que nos interesa atender es el texto con la definición inclusiva de 'epopeya' que fundamenta su estrafalaria concepción del Ars Poetica. Está en los umbrales mismos del comentario:

Artem Poeticam explicaturus operae pretium faciam, si altius rem deducens Horatii hoc loco breuitatem resarciam. Poesis ergo uera in opere epico perfecte constituendo tantum uersatur, quique hoc componere potest digne poetae nomen assumit, aliter cum fraude usurpat, ut infra ex Horatii uersis [sic] apparebit. Opus autem omne epicum, sub quo communi nomine narratiuum (ut Aristoteles apellat) siue heroicum tragicumque et comicum intelligimus, in actiones duas diuiditur: primariam scilicet et secundariam (fol. 101r.-101v.).

${ }^{23}$ IACOBI FALCONIS VALENTINI MONTESIANAE Operum poeticorum libri quinque (Mantuae Carpentanorum 1600), fols. 101r.-118v. (cito aquí por esta ed.); también, en la 2. "a ed. del mismo, OPERVM POETICORVM IACOBI FALCONIS VALENTINI Libri Quinque. Noua editio, quam plurimis eiusdem Auctoris operibus, quae nondum lucem viderant, locupletata, Barcinone 1624. Preparo en la actualidad una edición de esta obra, junto con la de otros comentarios renacentistas españoles al Ars; hasta su aparición, pueden consultarse las noticias que doy en la introd. a mi ed. de las Poesías Completas de Falcó (LeónCádiz-Sevilla, en prensa), vol. I, § 2.6 . 
¿Con qué fundamento atribuye el humanista semejante capacidad a la epopeya? La noción de que la épica - propiamente dicha, i. e., el poema heroicoconstituye el género matriz del que emanan la tragedia y la comedia es ciertamente antigua. Platón llamó a Homero «el más poético y primero de los trágicos» (Rep. 607 a 2); en la misma Poética, Aristóteles apuntó a la Ilíada y la Odisea como modelos o precursiones de la tragedia (1448 b 38 - 1449 a 1); el Pseudo-Plutarco propuso la Ilíada como paradigma generativo de la tragedia, y la Odisea, de la comedia, y esta idea se repite en el Renacimiento ${ }^{24}$. Tradicionalmente, además, la poesía se divide en tres géneros según el modo de imitación: 1) el narrativo, en el cual el poeta hace la imitación hablando por sí mismo; 2) el dramático o mimético, que realiza la imitación por boca de personajes presentados en actuación, género del que son representantes la tragedia y la comedia; 3) y el género común o, según más habitual denominación, mixto, que participa de aquellos dos, y que representa la poesía épica [cf. Platón, Rep. III 394 b-c; Diomedes (GLK I 482-483); Probo in Verg. Buc. (GLK VII 12); Isid. Orig. VII 7, 11, etc.]. Pero además de incluir en sí los dos modos posibles de imitación - $\mathrm{y}$ entre ellos el de la comedia y la tragedia-, el poeta épico es - modelo ideal renacentista - el poeta erudito, a quien asisten conjuntamente todos los conocimientos que conciernen a cada uno de los demás géneros, por separado ${ }^{25}$, y la epopeya puede $-\mathrm{y}$ hasta debeabordar todas las facultades del estilo poético y los géneros de la oratoria;

${ }^{24}$ Sobre la idea en la Antigüedad, cf. E. A. Ramos Jurado, «Homero, precursor de la tragedia y de la comedia", Minerva 1,1987 , pp. 75-83, v. pp. 76-80. Para Minturno la épica engendra todos los géneros literarios y contiene en sí los asuntos y estilos de cada uno; incluso la Iliada incluye material cómico: Hoc autem heroicum genus est, in quo quidem Homero atque Virgilio sane primas tribuimus. Ex illo enim fonte omnis poematum uarietas manauit. De Tragoedia quidem liquet, quae heroicam grauitatem secuta est. Comoediam non solum imitata est Odysseam, in qua uolunt expressum esse id quod Comicum appellant; sed etiam ex non uno Iliadis loco exemplum sibi petiuit, quod genus est, cum Vulcanum inducit, qui claudicans dum pocula Diis ministrabat, risum exitaret, ut certe haud sciam, an minus uere dictum sit usquequaque se Menandrum similem esse Homeri noluisse. In hoc certe illi se proximum esse optare debuisset, ut quem Homericus ille Vulcanus inter superos, ipse Athenis in theatro risum ciere potuisset. Deorum atque hominum laudes quomodo canantur, cum Phoemium aut Demodocum canentem facit, ille idem Homerus ostendit. At in ipsa carminum uarietate uis tanta est, ut eandem rem aliter alia genera poetarum tractare uideantur. Amores enim intemperantius Elegiaci, festiuius Comici. Miserabiles euentus immoderatius Tragici, laudes iucundius Lyrici quam Heroici illi, qui tamen haec omnia magis decore multoque ornatius explicant (pp. 105-106). En la Philosophia Antigua Poetica, el Pinciano admite la mezcla de elementos trágicos y cómicos en la epopeya, diciendo que «la Ulysea no es pura tragedia, sino mezclada de comedia. La Iliada tiene más de lo pathetico y está más en la perfección trágica» (cf. M. Menéndez y Pelayo, Historia de las ideas estéticas, Madrid 1929, III, p. 236).

${ }^{25}$ Cf. K. Werner, Die Gattung des Epos nach italienischen und französichen Poetiken des 16. Jahrhunderts, Francfort-Berna 1977, p. 10 y bibl. de A. Buck citada en n. 8; pp. $56,70,176$, etc. 
recuérdese el elogio de Quintiliano a Homero en su canon poético (I. O. X 1, 56-51), o repárese, una vez más, en las instrucciones de Minturno: Heroici autem sunt illi, qui soli omnium in hac triplici uarietate [estilo alto, medio, bajo] summa cum laude uersantur. Etsi enim in plerisque ac saepissime ampli et uehementes et copiosi existunt, interdum tamen subtilitatem simplicitatemque sequuntur, neque in paucis uel temperationem uel suauitatem non adhibent. Nam, ut id quoque de oratore ad poetam ex M. Tullio in hunc locum, quemadmodum et alia non pauca, transferamus, hic noster heroicus, quem ponimus principem, grauis, acer, ardens si ad hoc unum est natus, aut in hoc solo se exercuit, aut huic generi studet uni, nec suam copiam cum illis duobus generibus temperauit, maxime est contemnendus. Ille enim summissus, quod acute et ueteratorie dicit, sapiens iam, medius autem, quod aut temperanter aut iucunde suauis, hic uero copiosissimus, si nihil est aliud, uix satis sanus uideri solet. Itaque ut in dictione, ita in poemate, quod omnes laudes habet, id est optimum. (p. 105). Es indudable que este cuerpo de ideas tradicionales y vigentes en el Renacimiento, que atribuyen al poema épico - propiamente dicho- la capacidad de asumir el carácter específico de otros géneros, le puede haber sugerido a Falcó una autorización para ensanchar el término épica sometiendo bajo su dominio la comedia y la tragedia. Pero creo que también ha podido influir la lectura de Poética 1447 a 28 ss, obra a la que el valenciano recurre en otros lugares de su comentario: este pasaje también ampliaba explícitamente, siquiera en un nivel puramente designativo, los dominios del género, asignándole otras especies literarias como mimos y diálogos; pero sobre todo, aquella interpolación convertía a la epopeya en un 'nombre común' (ỏvo$\mu \alpha ́ \sigma \alpha$ kotvòv): no me parece una casualidad que Falcó también hable de la poesía épica como un commune nomen [Opus autem omne epicum, sub quo communi nomine narratiuum (ut Aristoteles apellat) siue heroicum tragicumque et comicum intelligimus]. Tal vez, en fin, corrobore la hipótesis el hecho de que un contemporáneo de nuestro valenciano - más célebre que él, por cierto- se base abiertamente en aquel lugar aristotélico para sostener la misma afirmación (la epopeya comprende la comedia y la tragedia). De él nos ocupamos a renglón seguido.

En su comentario, Vettori negaba la posibilidad de que Aristóteles concediera en este pasaje autorización alguna para componer comedias en prosa - cuya posibilidad, como la de la poesía sin verso, en general, fue motivo de animada polémica en el Renacimiento- ${ }^{26}$; de muy distinto modo opinaba uno

${ }^{26}$ [...] nec defuerint etiam nostra aetate uiri acuti lepidique ingenii, qui comoedias scripserint soluta oratione, quod (ut opinor) ueteres nunquam tentarunt, illos nanque in hoc parum uidisse puto, nec quicquam ipsos adiuuat, ut docui, testimonium huius loci, cum aliter accipiendus sit, ut ipse ostendere conatus sum; ac (nisi fallor) praestiti, quod contendi (p. 12). 
de los más conspicuos detractores de la necesidad del verso en el drama, Paolo Beni, autor de una Disputatio in qua ostenditur praestare comedias atque tragoedias metrorum uinculis soluere $(1600)^{27}$. Para utilizar las palabras del Estagirita en su provecho del modo que veremos, Beni se impone previamente la tarea de someterlas a una interpretación distinta de la de comentaristas anteriores como Vettori, Castelvetro, y los citados más arriba. Su discusión del pasaje es larga (pp. 382-393); expondré sólo los argumentos que me parecen más relevantes para nuestro presente objetivo. Traducir - razona - la expre-

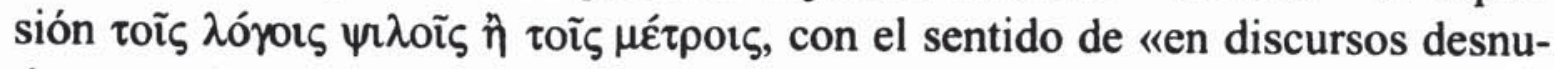
dos, o mejor dicho, en metro" constituye una interpretación artificiosa y errónea; no tiene sentido que Aristóteles, maestro sumo del buen decir, hubiera

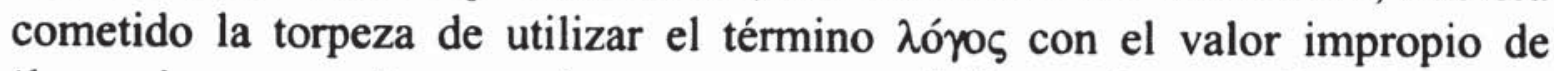
'lenguaje en verso' - cuando para expresar tal idea tenía a su disposición un término propio [sc. $\mu \varepsilon ́ \tau \rho o t \varsigma]-y$, en seguida, enmendase al precisar 'o mejor dicho, metro', reconociendo así un error que tan fácil le hubiera resultado evitar; y que después de enmendarse de tal modo, más abajo hubiera tropezado

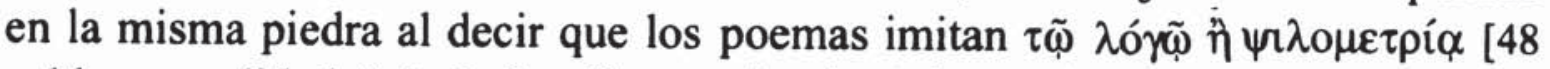

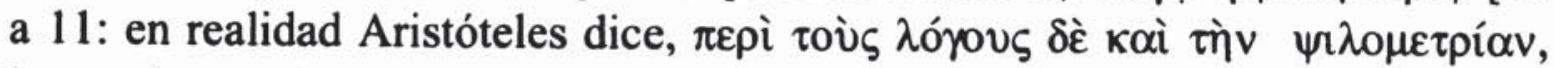
lo que juega aún más a favor de Beni], con lenguaje o sea metros desnudos ${ }^{28}$.

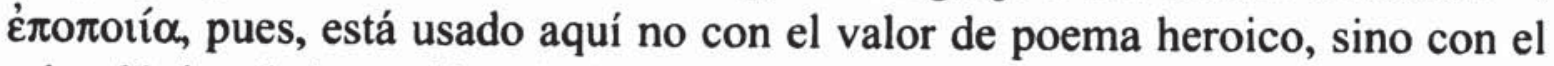
etimológico de 'creación o imitación hecha mediante el lenguaje, y de lenguaje de cualquier clase, sea en verso o sea en prosa' (cf. 'Wortdichtung'), uso lícito de acuerdo con uno de los sentidos que Eustacio le asigna a غ́лos: 1) palabra, dicho o lenguaje; 2) verso en general; 3) verso heroico. Por ello -continúaAristóteles reduce a la 'epopeya' los mimos de Sofrón y los diálogos platónicos: aquéllos, efectivamente, están en verso [Beni alude aquí a Vettori y suscribe su postura, cf. supra], y éstos, en prosa; pues pensar [aquí discrepa enérgicamente de Vettori] que los $\lambda$ ójoı $\Sigma \omega \kappa \rho \alpha \tau$ коì no son los diálogos pla-

27 El texto se encuentra en B. Weinberg, Trattati di poetica i retorica nel Cinquecento, Roma-Bari 1974, IV, pp. 345-398; para una valoración de la obra, cf. id., pp. 435-436 y, del mismo autor, A History..., I, pp. 244-246; II, pp. 706-707.

${ }^{28}$ Ego uero mirifice gaudeo quod aequos et auditores et rerum aestimatores in praesens offenderim, quique non asserant hic pro metro sermonem perpetuo usurpari posse (quod sine ulla Aristotelis authoritate quasi de tripode loquentes statuunt aliqui) neque Aristotelem contendant seipsum emendasse tandem, quasi sermonem pro metro usurpasse minus proprie, quod pugnant alii. Nam nihil erat quod summus dicendi artifex aut ferreis uocibus, ut ita dicam, plumbeisue uteretur, cum argenteas immo aureas haberet in promptu, aut eam culpam emendaret uel potius deprecaretur qua facillime carere potuisset; aut rursus, postquam eam, quod aduersarii dictitant, emendasset, epopoeiam imitari

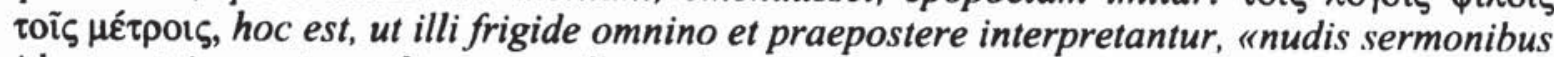
idest metris", aut "nudis sermonibus uel potius, ut rectius dicatur, metris», paulo post in

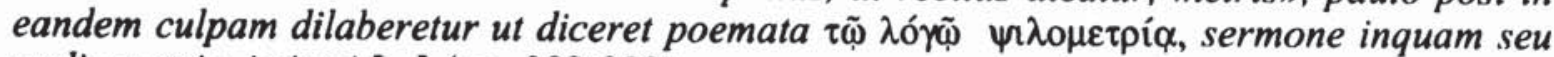
nudis metris, imitari [...] (pp. 382-383). 
tónicos, género en prosa, sino las fábulas de Esopo versificadas por Sócrates, no es más que un subterfugio artificiosísimo que cae por su propio peso: semejante concepción sería de todo punto incompatible con las referencias de Aristóteles en la Retórica [III 1417 a 21] de los mismos $\lambda$ óyor $\Sigma \omega \kappa \rho \alpha \tau$ «oì ${ }^{29}$. Y nadie piense - dice Beni- que el Estagirita emplea en confusa anfibología la palabra 'epopeya', ya sea como poema heroico, ya como creación en prosa o verso; él advierte haberlo tomado aquí con el segundo sentido en virtud de una carencia terminológica, como si dijera: «recuerdo que he dicho 'epopeya' desde el principio, y así seguiré haciéndolo en lo sucesivo, significando poema heroico; pero ahora, puesto que no hay nombre común para mimos y diálogos, permitidme que por un momento, para englobarlos bajo algún término, use 'epopeya' como 'cualquier imitación hecha mediante sólo el lenguaje' (valor que, por otra parte, puede tener el término como demostraba Eustacio)»" ${ }^{30}$.

Interpretado así el texto, ¿cómo se sirve de él Beni para justificar la tragedia y la comedia en prosa y de la mano de Aristóteles, y concederles un legítimo puesto entre los géneros literarios? Precisamente, reduciendo la tragedia y la comedia a la categoría de 'epopeya' (recuérdese a Falcó), mediante el siguiente silogismo: cualquier facultad poética que hace imitación, y que la hace no de cualquier cosa, sino de acciones humanas, y que imita acciones humanas no por cualquier medio, sino mediante el lenguaje, esa facultad, de acuerdo con Aristóteles, debe asimilarse a la epopeya y, por tanto, a un cierto género poético. Ahora bien, la tragedia y la comedia escritas en prosa hacen imitación, y la hacen de acciones humanas, y no por cualquier medio, sino a través del lenguaje. Así pues, la tragedia y la comedia

${ }^{29}$ Quamobrem qui socraticos sermones istos carmen quoddam dictitant cui Socrates morti proximus nescioquam Aesopi fabulam illigasset, ii mihi uideri solent perfrigidum omnino ruinosumque perfugium parasse, quandoquidem neque uerisimile est ut Aristoteles in libris De arte dicendi, ubi rursus socraticorum sermonum mentione iniecta asserebat hos moratos omnino fuisse et de moribus fuisse locutos, in carmen hymnumue illum inspiceret, contra uero perquam

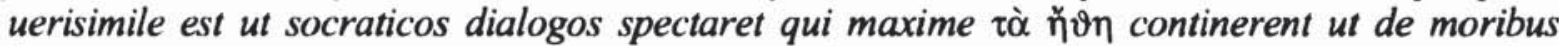
loquerentur; neque rationi est consentaneum ut ex hymno aut perbreui carmine isto tam amplam et imitationis et moratae orationis uim explicandi ansam arriperet neque rursus ut hymnum siue carmen sermonum nomine appellaret (pp. 384-385).

${ }^{30}$ Neque uero obiiciat mihi quisquam fore bilinguem Aristotelem qui epopoeiae nomen modo pro heroico carmen, modo pro sermone tam soluto quam etiam uincto usurpet. Nam hac ipsa de causa monebat se ad epopoeiam uarias illas imitationes (et uinctas scilicet et solutas) reuocare, quod aliud commune nomen suppeteret nullum, quasi diceret: "memini me ab initio 'epopoeiam' pro heroico carmine usurpare, eodemque quoque nomen a me usurpabitur in posterum; nunc tamen, quoniam nomen aliud suppetit nullum quo socraticos sermones una cum Sophronis et Xenarchi mimis (haec enim omnia sic imitantur ut tertio illo poetarum instrumento, sermone scilicet, seorsim utantur) certo aliquo imitationis instrumento adstringam, dabitis mihi hanc ueniam ut 'epopoeiam' pro quacunque imitatione solo sermone facta tantisper usurpans (nam id quoque ualere potest 'epopoeia') eiusmodi nomine poeticam imitationes illas concludam omnes et patefaciam quea harmonia et numero praetermissis solo sermone utuntur [...]" (p. 395). 
en prosa deben ser, de acuerdo con Aristóteles, asimiladas a la epopeya y, por tanto, a un determinado género poético ${ }^{31}$. No obstaría a tal conclusión el que el mismo Aristóteles diga en otro lugar de la Poética [1447 b 25-27] que la tragedia y la comedia usan ritmo, canto y verso; allí el Estagirita estaría refiriéndose sólo a unos requisitos consagrados en Grecia por la costumbre y el tiempo, y lo que aquí se inquiere no es qué hacían los cómicos y trágicos antiguos, sino si de acuerdo con el parecer de Aristóteles, la comedia y la tragedia se puede escribir en prosa (pp. 392-393).

El análisis que hace Beni del texto aristotélico es, salvando un par de puntos -1) consiente en la condición métrica de los mimos; 2) Aristóteles tiene mucho menos escrúpulo del que supone Beni en especificar sus diferentes usos de 'epopeya' (una de las razones, recordemos, que movían a secluir el vocablo)-, es, como digo, sensiblemente más lúcido y objetivo que el de sus predecesores Vettori, Castelvetro, y compañía. Ahora bien, su utilización del pasaje para los fines buscados es deficiente. Olvida Beni

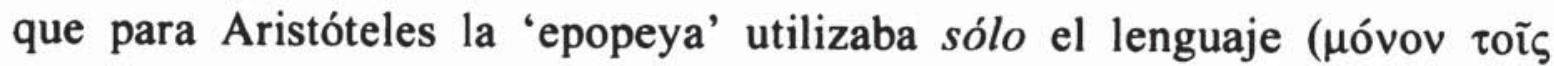

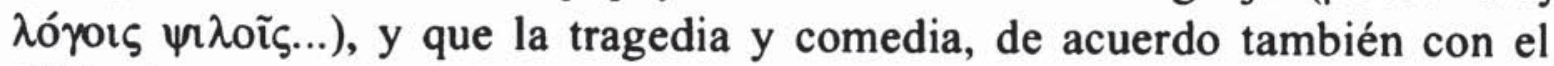
Filósofo, usa amén del lenguaje, el ritmo y el canto. El argumento - decisivo en su contra- de que Aristóteles atribuye el metro a la comedia y la tragedia está refutado tramposamente: no se ve por qué (si no es porque perjudica a la tesis de Beni) el Filósofo no expresa aquí, aparte de un uso consagrado por la práctica, su propia convicción sobre el drama. Y en fin, el italiano dice estar basando en la Poética su tesis de que el drama es posible en prosa, pero lo hace no a través de las instrucciones que da el autor griego sobre la tragedia, sino mediante un uso del término 'epopeya' que, según interpretación de Beni, el mismo Aristóteles estaría reconociendo como impropio y marginal. Pero por lo mismo, esta disquisición es interesante como documento sobre la relación en cierto modo paradójica que podían mantener los preceptistas de la época ante la Poética: como si de un libro sagrado se tratase, la necesitan imperiosamente, pero no dudan en manipularla, para sancionar sus postulados literarios.

En una apostilla a su traducción de la Poética de 1579, Antonio Riccoboni anotaba así el texto que aquí estudiamos: An Epopoeia possit fieri soluta ora-

${ }^{31}$ Quaecunque facultas imitatur nec quamlibet rem imitatur, sed humanas actiones; nec humanas actiones imitatur quocunque modo, sed sermone, ea ex Aristotele ad epopoeiam ac proinde ad certum quoddam poematis genus est reuocanda. Sed tragoedia atque comoedia soluta oratione conscripta imitatur; nec quancunque rem imitatur, sed humanas actiones imitatur non quocunque modo, sed sermone. Tragoedia itaque et comoedia quae soluta oratione conscripta sit ad epopoeiam ac proinde ad certum poematis genus ex Aristotelis sententia est reuocanda (p. 389). 
tione $^{32}$. La pregunta es peliaguda, ya que de ella dependía la legitimación, como género clásico parangonable a la epopeya en verso, de la novela moderna, alumbrada desde la concepción de 'epopeya en prosa' ${ }^{33}$. La cuestión constituye un dominio de historiadores de la literatura moderna $-\mathrm{y}$ entre ellos, como veremos, tiene especial interés para los hispanistas-y como tal escapa a mis conocimientos; sin embargo, por la conexión central que tiene con el texto aquí estudiado, no me resisto a asomarme, siquiera tímidamente, a esta atractiva parcela. No fueron, en efecto, pocos los preceptistas del siglo XVI que favorecieron la posibilidad de una épica en prosa: los ejemplos típicos que se pueden citar al respecto son Julio César Escalígero y, en España, Alonso López el Pinciano, que consideraban como modelo de epopeya las Etiópicas de Heliodoro ${ }^{34}$. Ahora bien, un aristotélico como el Pinciano ${ }^{35}$ sin duda obtuvo en el Filósofo la autorización para mantener tan novedosa postura: el Estagirita no sólo sugería que el metro no es necesario o distintivo de la poesía; asimismo decía positiva e explícitamente en Poética 1447 a 28 -l lugar que anotaba con aquel interrogante Riccoboni-que «la epopeya imita tanto en prosa como en verso" ${ }^{36}$. Como también Cervantes debe en último término a Aristóteles - sea por mediación del Pinciano, reconocida fuente suya, sea a partir de poéticas como las de Minturno o Viperano, vistas más arriba o de comentarios a la Poética como el de un Robortello- la frase final de un famoso pasaje del Quijote (I, IV 47), considerado entre los expertos como clave para su teoría de la novela:

$\mathrm{Y}$ siendo esto hecho con apacibilidad de estilo y con ingeniosa invención, que tire lo más que fuere posible a la verdad, sin duda compondrá una tela de varios y hermosos lazos tejida, que después de acabada, tal perfección y hermosura muestre, que consiga el fin mejor que se pretende en los escritos, que es enseñar y deleitar juntamente, como ya tengo dicho. Porque la escritura desatada destos libros da lugar a que el autor pueda mostrarse épico, lírico, trágico, cómico, con todas aquellas partes que encierran en sí

${ }^{32}$ Cf. Weinberg, A History..., I, p. 584.

${ }^{33}$ Remito, para situación general de la cuestión y abundantísima bibliografia, a A. Egido, "Las fronteras de la poesía en prosa", Edad de Oro 3, 1984, pp. 67-95 (= Las fronteras de la poesia en el Barroco, Zaragoza 1990, pp. 84-114, por donde cito), v. esp. p. 105 ss.

${ }_{34}$ Cf. A. Forcione, Cervantes, Aristotle, and the Persiles, New Jersey 1970, p. 64 ss.

${ }^{35}$ Cf. S. Shepard, El Pinciano y las teorias literarias del Siglo de Oro, Madrid 1970.

36 Ya Forcione intuyó por dónde iban los tiros, cf. op. cit. pp. 98-99, n. 16; este autor, sin embargo, no se aclara demasiado sobre cuál es la fuente exacta de Aristóteles que hay tras el Pinciano e incluso se plantea la posibilidad de que al decir «la épica haze su imitación con sólo lenguaje o metro" esté traduciendo mal a Aristóteles: «I find support for my interpretation in El Pinciano's discussion of Aristotle's words 'la épica haze su imitación con sólo lenguaje o metro' [whether this is or is not a mistranslation of the Poetics, xxiii (?), need not concern us here] to suggest that the prince of philosophers may have allowed an epic in prose. He interprets the phrase as meaning 'agora sea lenguaje suelto, agora atado, es suficiente para la épica'». 
las dulcísimas y agradables ciencias de la poesía y de la oratoria; que la épica también puede escribirse en prosa como en verso ${ }^{37}$.

Obsérvese que tal concepto de 'epopeya', en el texto original de Aristóteles, era absolutamente relativo al contexto: se trataba, según observaban Vettori, Minturno o el mismo Beni, de un uso anómalo del término forzado por una necesidad terminológica; y es que para Aristóteles, 'epopeya' es normalmente imitación en verso heroico. No parece que hayan sabido (o querido) ver esto el Pinciano y, con él, Cervantes: las palabras del Estagirita son sacadas de su contexto original y se toman como aserto absoluto; no proporcionan un verdadero argumento de autoridad, son una mera excusa verbal utilizada para avalar la práctica de una épica en prosa. En prosa, o en mezcla de prosa y verso, que también la frase se prestaba a la interpretación: sirva como ejemplo Francisco Cascales, que también acoge en sus Tablas Poéticas el texto de Aristóteles y lo ilustra proponiendo como ejemplo moderno de épica en prosa $y$ verso las novelas pastoriles ${ }^{38}$. Y en fin, esta sanción de la epopeya en prosa, propiciada por la frase aristotélica, permite la transferencia a la novela de aquellas cualidades que ya estaban permitidas desde antiguo para la poesía heroica (la capacidad de asumir los diferentes estilos, temas y condiciones de los demás géneros; recuérdese el texto, más arriba, de Minturno, y compárese con el de Cervantes), y que acaso contribuyen a someter a la novela a una dinámica de expansión que la convierte en el género literario global, en la escritura desatada en la que todo cabe, en el proverbial «cajón de sastre».

\section{Daniel LóPez-Cañete Quiles}

37 Cito por la ed. de J. J. Allen, Madrid 1992 15, p. 555. Forcione (op. et loc. cit) puso en conexión este texto de Cervantes con el pasaje del Pinciano cuya exacta ascendencia aristotélica, sin embargo, no llegó a determinar.

38 «La Poesía Epica no se viste de los ornamentos, que prestan la música y la danza a sus hermanas para deleitar, más texe su tela con medidas en versos, qual en el heroico y bucólico poema se ve, o es un decir suelto, que comúnmente se llama prosa. Porque los Diálogos de los antiguos, y muchos Mimos, ¿que otra cosa son que prosas poéticas? Xenarco y Sophrón y otros hicieron Mimos, que fue una manera de Comedia en prosa, ya no usada [...]. Así que sola la Epopeia puede hacer su imitación en prosa y verso: pero nosotros trataremos de la métrica. La Epopeia pues es el poema Heroico, Eclogas, Sátiras, Elegías y qualquier poesía, donde para su ser perfecto no se requiere baile, ni canto [cf. supra Minturno]. Desta misma especie podemos llamar los Cantos o Capitulos de Dante Alighiero, en que trató divinamente del Purgatorio, del Infierno, y del Paraíso [...]; y en nuestra compostura de arte mayor las Trecientas de Juan de Mena [...]. También hallaréis Poesía vulgar de la una y otra Epica manera, es a saber en prosa y en verso, qual es la Arcadia de Sannazaro, el Ameto del Bocacio, el Amor enamorado de Minturno, la Diana de Montemayor, y el Pastor de Filida de Montalvo" (II, tabla sexta, 1, ed. A. García Berrio, Madrid 1988, pp. 286-287). 